\title{
Growth-rate-dependent adjustment of ribosome function in the fungus Mucor racemosus
}

\author{
Michael ORLOWSKI \\ Department of Microbiology, Louisiana State University, Baton Rouge, LA 70803, U.S.A.
}

(Received 27 August 1980/Accepted 14 January 1981)

\begin{abstract}
The dimorphic fungus Mucor racemosus was grown at rates between 0.043 and 0.434 doubling/h while maintained as yeasts or at rates between 0.21 and 0.50 doubling $/ \mathrm{h}$ while maintained as hyphae by altering the composition of the growth medium or the gaseous environment of the cells. Yeasts at the higher growth rates contained many more ribosomes than did yeasts at the lower growth rates. They also had a higher percentage of ribosomes active in protein synthesis and a faster rate of polypeptide-chain elongation than did the slower-growing cells. Hyphal cells at faster growth rates also contained many more ribosomes and showed a faster rate of polypeptide-chain elongation than did slower-growing cells. However, the faster-growing cells had a substantially lower proportion of ribosomes active in protein synthesis than did the slower-growing hyphae. Pulse-chase experiments failed to provide any evidence of protein turnover, which might otherwise invalidate the values calculated for the peptide-chain elongation rates.
\end{abstract}

There are essentially only two ways in which a cell can regulate the overall rate of protein synthesis: (i) adjustment of the rate of nascent polypeptide-chain elongation and (ii) adjustment of the number of nascent polypeptide chains. The rate of peptidechain elongation as a function of cell growth rate has been studied extensively in bacteria. Most of the early work suggested a constant value for this parameter (Coffman et al., 1971; Forchhammer \& Lindahl, 1971; Dalbow \& Young, 1975; Young \& Bremer, 1976). This contention has been challenged, and a more pliable relationship between the rate of translation and the rate of cell growth, especially at slow growth rates, has been proposed (Forchhammer \& Lindahl, 1971; Martin \& Iandolo, 1975; Young \& Bremer, 1976).

There has been relatively little work done relating peptide-chain elongation rates and cell growth rates of eukaryotic micro-organisms. What little has been published on the subject abounds with contradictions. Boehlke \& Friesen (1975), using a method based on the recovery of active polyribosomes, determined that the peptide-chain elongation rate varied linearly with the growth rate over a 5-fold

Abbreviations used: TMK buffer, $50 \mathrm{mM}-\mathrm{Tris} / \mathrm{HCl}$ (pH 7.25), $10 \mathrm{~mm}$-magnesium acetate, $500 \mathrm{mM}-\mathrm{KCl}$; TMKC buffer, TMK buffer containing $200 \mu \mathrm{g}$ of cycloheximide $/ \mathrm{ml}$. range of doubling times in the fungus Saccharomyces cerevisiae. Bonven \& Gulløv (1979) corroborated these findings in $S$. cerevisiae, using a method by Gausing (1972) based on the kinetics of radioactive labelling of nascent and completed polypeptides. In contrast, Waldron et al. (1977), using the same organism and the same method as Bonven \& Gulløv (1979), concluded that the rate of amino acid addition to growing protein chains was constant. Alberghina \& Sturani (1975) studied Neurospora crassa, using methods similar to those of Boehlke \& Friesen (1975); however, they found little variance in the peptide-chain elongation rate over a 7-fold range of growth rates. Orlowski \& Sypherd (1978a), using both types of methodology, reported a 4-fold increase in the rate of peptide-chain elongation during yeast-to-hypha conversion in the fungus Mucor racemosus. This morphogenetic process is accompanied by a 3-fold increase in the cellular growth rate.

Adjustment of the percentage of ribosomes actively engaged in translation is the major alternative mechanism for regulating the overall rate of protein synthesis. This parameter has also been studied as a function of growth rate in the above-mentioned fungal systems. Boehlke \& Friesen (1975), as did Alberghina \& Sturani (1975), found the percentage of active ribosomes to be constant over a wide range of growth rates. To the contrary, 
Waldron et al. (1977) and Bonven \& Gulløv (1979) reported a greater percentage of active ribosomes in faster-growing cells than in slower-growing cells, whereas Orlowski \& Sypherd (1978a) found a higher proportion of active ribosomes in the slowergrowing than in the faster-growing cells.

In the present study I have grown the fungus $M$. racemosus in either the yeast or hyphal form exclusively over a wide range of growth rates by controlling the nutrients in the medium or the gaseous environment of the cells. I was thus able to study the regulation of the overall rates of protein synthesis in this organism uncoupled from cellular morphogenesis.

\section{Materials and methods}

\section{Organism and growth conditions}

Mucor racemosus (A.T.C.C. 1216B), a leucine auxotroph (leu-2A) derived from this strain (Peters \& Sypherd, 1978), or a mutant strain (coy) that can grow only as a yeast in the absence of added methionine (Sypherd et al., 1979), were used in these experiments. Several different growth media were used. YPG medium contained $0.3 \%(\mathrm{w} / \mathrm{v})$ yeast extract, $1.0 \%$ (w/v) Bactopeptone (Difco, Detroit, MI, U.S.A.) and $2.0 \%(\mathrm{w} / \mathrm{v})$ glucose. All of the defined media contained the following vitamins and basal salts (per litre): $1 \mathrm{mg}$ of biotin, $1 \mathrm{mg}$ of thiamin, $0.5 \mathrm{~g}$ of $\mathrm{KH}_{2} \mathrm{PO}_{4}, 0.5 \mathrm{~g}$ of $\mathrm{Na}_{2} \mathrm{HPO}_{4}, 0.5 \mathrm{~g}$ of $\mathrm{MgSO}_{4}, 20 \mathrm{mg}$ of $\mathrm{MnSO}_{4}, 10 \mathrm{mg}$ of $\mathrm{CaCl}_{2}, 10 \mathrm{mg}$ of $\mathrm{ZnSO}_{4}, 10 \mathrm{mg}$ of $\mathrm{FeCl}_{3}$ and $10 \mathrm{mg}$ of $\mathrm{CuSO}_{4}$. All yeast cultures were supplemented with $1.5 \mathrm{~g}$ of sodium glutamate, $1 \mathrm{~g}$ of $\left(\mathrm{NH}_{4}\right)_{2} \mathrm{SO}_{4}$ and $2 \mathrm{~g}$ of glucose (all per litre). Hyphal cultures were supplemented with $2 \mathrm{~g}$ of glucose or $2 \mathrm{~g}$ of mannitol as a carbon source and $1 \mathrm{~g}$ of $\left(\mathrm{NH}_{4}\right)_{2} \mathrm{SO}_{4}$ or $1 \mathrm{~g}$ of urea as a nitrogen source (all per litre). Cultures of the leucine auxotroph were supplemented with $100 \mu \mathrm{g}$ of L-leucine $/ \mathrm{ml}$. All media were adjusted to $\mathrm{pH} 4.5$ with conc. $\mathrm{H}_{2} \mathrm{SO}_{4}$. All cultures were inoculated with $5 \times 10^{5}$ sporangiospores $/ \mathrm{ml}$. The spores were prepared as previously described (Orlowski, 1979) and washed with distilled water before inoculation. All cultures were grown at $22^{\circ} \mathrm{C}$ with shaking. Cultures were sparged with water-saturated air, $100 \% \mathrm{~N}_{2}$ or $100 \% \mathrm{CO}_{2}$ as appropriate. Growth was monitored by measuring the $A_{600}$ of the cultures. Concomitant with each absorbance measurement, samples of culture were collected and stored frozen for later measurement of protein and RNA. All cultures were allowed to grow to an $A_{600}$ of 0.4-0.6 before use in any experiment. At such time all yeasts had multiple buds, and all hyphal cells had short germ tubes approx. 2-10 spore diameters in length.

\section{Determination of active ribosomes}

The procedure of Orlowski \& Sypherd (1978a) was used to measure the proportion of ribosomes active in protein synthesis. Cycloheximide $(200 \mu \mathrm{g} /$ ml final concn.) was added to the culture medium. After 2 min the cells were collected on a membrane filter (Millipore Corp., Type AA, pore size $0.8 \mu \mathrm{m}$ ), washed briefly with cold TMKC buffer and ground under liquid $\mathrm{N}_{2}$ with a mortar and pestle. The broken cells were resuspended in TMKC buffer and centrifuged at $15000 \mathrm{~g}$ for $10 \mathrm{~min}$ at $4^{\circ} \mathrm{C}$. A volume of the supernatant fraction containing $4.0 A_{260}$ units was layered on a $10-40 \%(w / w)$ linear sucrose gradient (in TMK buffer, $11.0 \mathrm{ml}$ ) resting on a $60 \%$ $(\mathrm{w} / \mathrm{w})$ sucrose cushion $(0.8 \mathrm{ml})$. Gradients were centrifuged in an SW41 rotor (Beckman) at $150000 \mathrm{~g}$ for $80 \mathrm{~min}$ at $4^{\circ} \mathrm{C}$. The gradients were scanned at $254 \mathrm{~nm}$ with an ISCO model 640 density-gradient fractionator. Previous analyses (Orlowski \& Sypherd, 1978a) of the material on the gradients indicated properties diagnostic of polyribosomes, 80S, monoribosomes and $60 \mathrm{~S}$ and $40 \mathrm{~S}$ ribosomal subunits. Altering the centrifugal force $(5000 \mathrm{~g}$ to $27000 \mathrm{~g})$ in the preparatory step or treatment of the broken cell suspensions with Triton $\mathrm{X}-100$ or deoxycholate did not change the ribosome profiles obtained on the gradients. Further extraction of the $15000 \mathrm{~g}$ pellets with buffer or the aforementioned detergents liberated only small amounts of polyribosomes, which had the same size distribution as found in the initial supernatant fractions. Treatment of the broken cell suspensions with ribonuclease $\mathrm{A}$, which converts all polyribosomes into $80 \mathrm{~S}$ particles, did not change the observed subunit/active-ribosome ratios. Though the existence of a potential population of membranebound or very heavy polyribosomes not quantitatively recovered in these procedures is possible, the above observations minimize this possibility. The procedure of Forchhammer \& Lindahl (1971) was previously used to show that all polyribosomes and all $80 \mathrm{~S}$ monoribosomes in Mucor are active in translation (Orlowski \& Sypherd, 1978a). The correct determination of active ribosomes thus includes the sum of all polyribosomes plus all $80 \mathrm{~S}$ monoribosomes.

\section{Protein and RNA measurements}

Total cellular protein was measured by the procedure of Lowry et al. (1951). Total cellular RNA was measured by the method of Cheung $e t$ al. (1974). The proportion of total cellular RNA representing rRNA was determined by fractionating purified RNA on sucrose-density gradients by the method of Orlowski \& Sypherd (1978b).

\section{Cellular ribosome density}

The number of ribosomes per $\mathrm{g}$ of total cellular 
protein was calculated from the following relationship: obtained were plotted and interpreted as described by Scornik (1974).
RNA $\times \%$ of rRNA $\times$ Avogadro's number

Protein $\times$ mol.wt. of rRNA

Protein, RNA and the \% of rRNA were determined as described above. The combined molecular weights of rRNA species from $M$. racemosus as reported by Lovett \& Haselby (1971) was $2.04 \times$ $10^{6}$. Avagadro's number is $6.02 \times 10^{23}$.

\section{Calculation of peptide-chain elongation rates}

Peptide-chain elongation rates were calculated as described by Forchhammer \& Lindahl (1971). The parameters measured were those necessary to complete the following relationship:
$=$ no. of ribosomes $/ \mathrm{g}$ of protein

\section{Assay for protein turnover}

Portions $(2 \mathrm{ml})$ of a culture were transferred to small test tubes $(13 \mathrm{~mm} \times 100 \mathrm{~mm})$, where bubbling with the appropriate gas was continued. A radioactive amino acid $\left(\mathrm{L}-\left[{ }^{14} \mathrm{C}\right]\right.$ valine, $\mathrm{L}-\left[{ }^{14} \mathrm{C}\right]$ proline or $\mathrm{L}-\left[{ }^{14} \mathrm{C}\right.$ leucine) was added to a final concentration of $2.5 \mu \mathrm{Ci} / \mathrm{ml}$. Portions $(100 \mu \mathrm{l})$ of the culture were removed at intervals and placed into $1 \mathrm{ml}$ of $10 \%$ $(w / w)$ trichloroacetic acid. Samples were heated for $20 \mathrm{~min}$ at $90^{\circ} \mathrm{C}$ and then chilled for $30 \mathrm{~min}$ at $0^{\circ} \mathrm{C}$.

\section{(Protein $/ 120) \times \mu \times \ln 2$ \\ (rRNA/mol.wt. of rRNA) $\times \%$ of active ribosomes $\times 3600=$ no. of amino acids $/ \mathrm{s}$ per ribosome}

where $\mu$ is the growth rate in doublings $/ \mathrm{h}, \ln 2$ is from the growth-rate equation, 3600 is the number of $s / h$ and 120 represents the average molecular weight of the 20 naturally occurring L-amino acids. Total cellular protein, rRNA and the percentage of active ribosomes were measured as described above. The molecular weights of the rRNA species from $M$. racemosus were previously reported (Lovett \& Haselby, 1971).

\section{Transit-time determinations}

For this, $200 \mathrm{ml}$ of leucine-auxotroph cells in mid-exponential growth $\left(A_{600}=0.4-0.6\right)$ were collected on a membrane filter and resuspended in $50 \mathrm{ml}$ of fresh medium contained in a large syringe barrel fixed vertically and fitted with a three-way stopcock. The medium was sparged with the appropriate gas $\left(\mathrm{N}_{2}, \mathrm{CO}_{2}\right.$ or air). Then $50 \mu \mathrm{Ci}$ of $\mathrm{L}-\left[{ }^{3} \mathrm{H}\right]$ leucine was rapidly injected into the culture and $5 \mathrm{ml}$ portions were drawn at intervals into $5 \mathrm{ml}$ of an ice-cold solution of cycloheximide $(500 \mu \mathrm{g} / \mathrm{ml})$ and $\mathrm{NaN}_{3}$ $(10 \mathrm{~mm})$. The labelled cells were collected on a membrane filter, washed with cold TMKC buffer and broken under liquid $\mathrm{N}_{2}$. The broken cells were resuspended in TMKC buffer and centrifuged at $15000 \mathrm{~g}$ for $10 \mathrm{~min}$ at $4^{\circ} \mathrm{C}$. The supernatant fluid (S-15) was recovered and a portion of it centrifuged at $150000 \mathrm{~g}$ for $3 \mathrm{~h}$ at $4^{\circ} \mathrm{C}$, which yielded a second supernatant fraction (S-150). This centrifugation step separated labelled nascent polypeptides (ribosome-bound, in the pellet) from labelled completed protein molecules (released into the S-150 fraction). Protein in the S-15 and S-150 fractions was precipitated in 1ce-cold $10 \%(\mathrm{w} / \mathrm{w})$ trichloroacetic acid, collected on glass-fibre filters (Reeve-Angel, Clifton, NJ, U.S.A.), dried under a heat lamp and assayed for radioactivity by liquid-scintillation spectroscopy (Orlowski \& Sypherd, 1977). The data
The precipitates were collected on glass-fibre filters, washed with ice-cold $10 \%$ trichloroacetic acid, dried under a heat lamp and assayed for radioactivity by liquid-scintillation spectroscopy (Orlowski \& Sypherd, 1977). After $20 \mathrm{~min}$, a chase of 200 -fold excess unlabelled amino acid was added to the culture and the assay of acid-insoluble radioactivity continued as above.

\section{Chemicals}

All biochemicals were obtained from Sigma Chemical Co., St. Louis, MO, U.S.A. All inorganic chemicals were purchased from Mallinckrodt Chemical Works, St. Louis, MO, U.S.A., and were of analytical grade. $\mathrm{L}-\left[3,4,5-{ }^{3} \mathrm{H}\right]$ Leucine $(118.3 \mathrm{Ci} /$ $\mathrm{mmol})$, L-[U-14 $\mathrm{C}]$ leucine $(289 \mathrm{mCi} / \mathrm{mmol}), \mathrm{L}-[\mathrm{U}-$ $\left.{ }^{14} \mathrm{C}\right]$ valine $(250 \mathrm{mCi} / \mathrm{mmol})$ and $\mathrm{L}-\left[\mathrm{U}-{ }^{14} \mathrm{C}\right]$ proline $(238 \mathrm{mCi} / \mathrm{mmol})$ were obtained from New England Nuclear Corp., Boston, MA, U.S.A.

\section{Results}

\section{Manipulation of cellular growth rate}

Figs. $1(a)$ and $1(b)$ respectively show the growth response of Mucor yeasts and Mucor hyphae under a variety of nutritional and atmospheric conditions. Growth rates, expressed in mass doublings $/ \mathrm{h}$, were calculated from the slopes of the curves in Figs. 1(a) and $1(b)$ and are displayed alongside the appropriate growth curves. The yeasts showed a 10-fold variance in growth rate, whereas the hyphae exhibited only a 2.5 -fold range for this parameter.

Cellular ribosome population and rate of peptide-chain elongation

Tables 1 and 2 respectively show how the growth rate of Mucor yeasts and Mucor hyphae correlate with the RNA/protein ratio and with several other 
Table 1. Polypeptide-chain elongation rate and other measured parameters as a function of growth rate in Mucor yeast cells

For full details, see the Materials and methods section. 'YPG' is yeast-peptone-glucose medium (see the Materials and methods section). Glc-Glu- $\mathrm{NH}_{3}$ medium contains vitamins and salts as described in the Materials and methods section, glucose $(\mathrm{Glc})$ as carbon source, and glutamate $(\mathrm{Glu})$ and $\left(\mathrm{NH}_{4}\right)_{2} \mathrm{SO}_{4}\left(\mathrm{NH}_{3}\right)$ as nitrogen source.

Growth conditions

\begin{tabular}{|c|c|c|c|}
\hline Medium & Atmosphere & (doubling/h) & $\begin{array}{l}\text { RNA/protein } \\
\text { (w/w) }\end{array}$ \\
\hline $\begin{array}{l}\text { YPG } \\
\text { YPG } \\
\text { Glc-Glu-NH } \\
\text { Glc-Glu-NH }\end{array}$ & $\begin{array}{l}\mathrm{N}_{2} \\
\mathrm{CO}_{2} \\
\mathrm{CO}_{2} \\
\mathrm{Air}^{*}\end{array}$ & $\begin{array}{l}0.434 \\
0.179 \\
0.050 \\
0.043\end{array}$ & $\begin{array}{l}0.49 \\
0.37 \\
0.134 \\
0.142\end{array}$ \\
\hline
\end{tabular}

No. of ribosomes per $\mathrm{g}$ of protein $12.5 \times 10^{16}$ $9.4 \times 10^{16}$ $3.4 \times 10^{16}$ $3.6 \times 10^{16}$
Polypeptide-chain

Percentage of elongation rate (amino active acid molecules added/ ribosomes $\quad s$ per ribosome)

85.9 5.5

$82.0 \quad 2.2$

$\begin{array}{ll}75.5 & 1.8\end{array}$

$\begin{array}{ll}71.5 & 1.9\end{array}$

* Conditional yeast (coy) mutant grows as a yeast in air in the absence of methionine.

Table 2. Polypeptide-chain elongation rate and other measured parameters as a function of growth rate in Mucor hyphae For full details, see the Materials and methods section. 'YPG' is yeast-peptone-glucose medium (see the Materials and methods section). The other media contain vitamins and salts as described in the Materials and methods section, glucose (Glc) or mannitol (Man) as carbon source, and $\left(\mathrm{NH}_{4}\right)_{2} \mathrm{SO}_{4}\left(\mathrm{NH}_{3}\right)$ or urea as nitrogen source.

Growth conditions

\begin{tabular}{lccc}
\multicolumn{1}{c}{ Medium } & Atmosphere & $\begin{array}{c}\mu \\
\text { (doubling/h) }\end{array}$ & $\begin{array}{c}\text { RNA/protein } \\
(\text { w/w) }\end{array}$ \\
YPG & Air & 0.50 & 0.47 \\
YPG & $\mathrm{N}_{2}$ & 0.43 & 0.47 \\
Glc-NH & Air & 0.33 & 0.34 \\
Glc-urea & Air & 0.24 & 0.33 \\
Man- NH $_{3}$ & Air & 0.21 & 0.22
\end{tabular}

No. of ribosomes per $\mathrm{g}$ of protein $12.0 \times 10^{16}$ $12.0 \times 10^{16}$

$8.6 \times 10^{16}$

$8.3 \times 10^{16}$ $5.6 \times 10^{16}$
Polypeptide chain Percentage of elongation rate (amino active acid molecules added/ ribosomes

60.8 s per ribosome)

45.7 6.7

86.0

84.1

75.3
7.7

4.3

3.3

4.8 parameters each having the potential for altering the overall rate of protein synthesis. Examples of the quality of RNA resolution and ribosomal resolution achieved in the present systems have been published (Orlowski \& Sypherd, 1978a,b). The percentage of rRNA was a relatively constant $85.7 \pm 2.3 \%$ (mean \pm S.E.M., $n=8$ ) over a wide range of growth conditions. Cells of relatively fast-growing yeasts and hyphae contained more ribosomes and had faster rates of peptide-chain elongation than did relatively slow-growing cells. When these parameters were plotted versus growth rate, a linear relationship was observed in both cases (Figs. $2 a$ and $2 b$ ). The percentage of ribosomes active in protein synthesis did not relate to growth rate in such a straightforward manner. In yeasts there was an increase, though not a linear one, in the proportion of ribosomes active at increasing growth rates (Table 1). However, in hyphae nearly the converse was true. Some slower-growing cells had a higher fraction of ribosomes active in protein synthesis than faster growing cells (Table 2).

\section{Transit time of $m R N A$ translation}

The transit time is the period of time required for a ribosome to bind to an mRNA molecule, complete translation and release a finished polypeptide. The kinetics of transfer of radioactive amino acids from nascent peptide chains to completed proteins are directly related to the transit time (Haschemeyer, 1969; Fan \& Penman, 1970; Scornik, 1974). Centrifugation at $150000 \mathrm{~g}$ was used to separate broken cells into a ribosome fraction, where labelled nascent peptides were located, and a supernatant fraction, where labelled completed proteins were found (see the Materials and methods section). The distribution of label between these two fractions after a pulse of $\mathrm{L}-\left[{ }^{3} \mathrm{H}\right]$ leucine was measured over short time intervals and plotted as the fraction of radioactivity in nascent protein $(\mathrm{N} / \mathrm{T})$. Transit times were calculated for Mucor yeasts and hyphae at several growth rates from the decay kinetics of N/T (Fig. 3) as described by Scornik (1974). The calculated transit-time values are presented in Table 3 (column 5). Assuming that there is no major change in the molecular-weight distribution of proteins made at the different growth rates, the peptide-elongation rates and transit-time values should change in a strict relationship with one another, expressed in the following equation: 

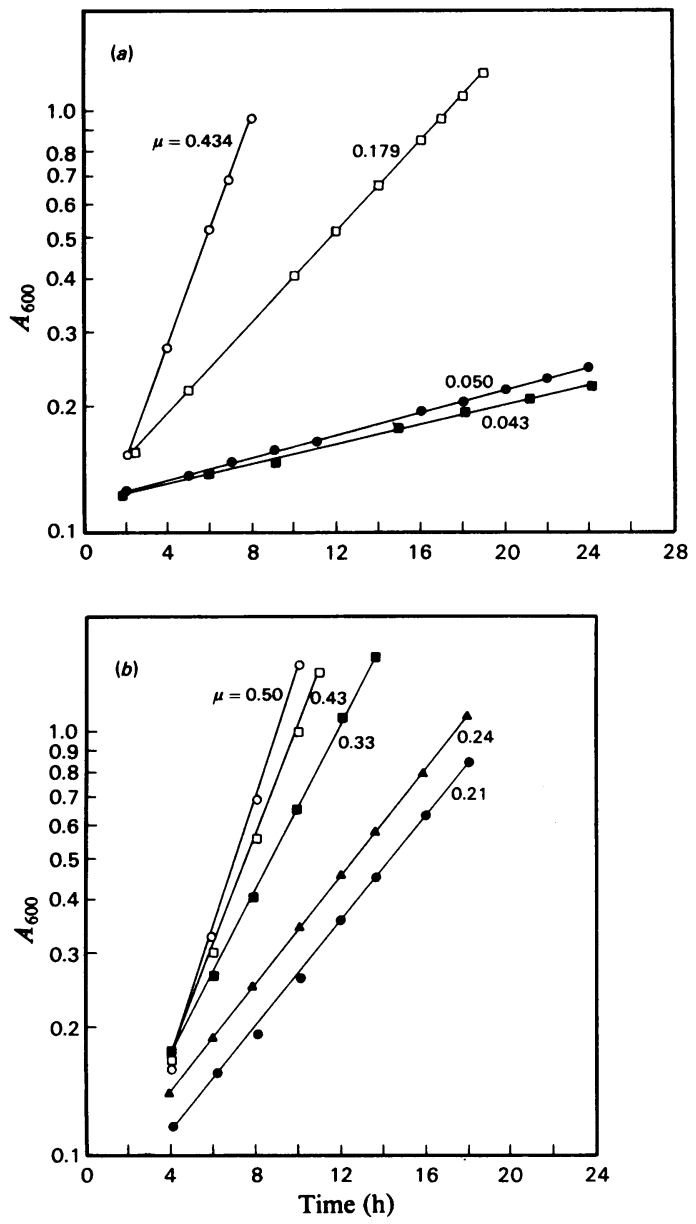

Fig. 1. Growth kinetics of Mucor yeasts and hyphae under various nutritional and gaseous environments Growth rates $(\mu)$, expressed in mass doublings/h, were calculated from the slopes of the growth curves and are displayed alongside the appropriate curves. (a) Yeasts. Symbols: O, YPG medium, $\mathrm{N}_{2}$ atmosphere; $\square$, YPG medium, $\mathrm{CO}_{2}$ atmosphere; $\boldsymbol{\bullet}$, defined medium (see the Materials and methods section) with glucose, glutamate and $\left(\mathrm{NH}_{4}\right)_{2} \mathrm{SO}_{4}$, $\mathrm{CO}_{2}$ atmosphere; $\boldsymbol{\square}$, defined medium as above, air atmosphere, coy mutant strain (all other experiments performed with strain 1216B). (b) Hyphae. Symbols: O, YPG medium, air atmosphere; $\square$, YPG medium, $\mathrm{N}_{2}$ atmosphere; $\mathbf{a}$, defined medium with glucose and $\left(\mathrm{NH}_{4}\right)_{2} \mathrm{SO}_{4}$, air atmosphere; $\Delta$, defined medium with glucose and urea, air atmosphere; $\boldsymbol{\bullet}$, defined medium with mannitol and $\left(\mathrm{NH}_{4}\right)_{2} \mathrm{SO}_{4}$, air atmosphere. All experiments were performed with strain 1216B.

Since the calculated average protein molecular weights are a product of the two measured parameters, they should not vary significantly from one another if the methods used are reliable and the measurements accurate. Such calculations have been made by using the appropriate values of the peptide-elongation rate (column 6 of Table 3) taken from Tables 1 and 2 . The calculated values appear in column 7 of Table 3 and are relatively constant. Thus the data from the two methods correlate quite well.

\section{Protein turnover}

One important assumption made, which must be true in order for the calculated peptide-elongation rates to be valid, is that protein turnover does not occur to any significant degree. Mucor cells pulselabelled with a radioactive amino acid under a wide variety of different growth conditions never released a significant amount of radioactivity after a chase with unlabelled amino acid. Figs. $4(a)$ and $4(b)$ show representative results for hyphal cells growing in various media under air with $\mathrm{L}-\left[{ }^{14} \mathrm{C}\right]$ valine or $\mathrm{L}-\left[{ }^{14} \mathrm{C}\right]$ proline respectively as the label. Identical results were obtained for yeast cells under $\mathrm{CO}_{2}$ or $\mathrm{N}_{2}$ with these amino acids or $\mathrm{L}-\left[{ }^{14} \mathrm{C}\right]$ leucine or $\mathrm{L}$ $\left[{ }^{14} \mathrm{C}\right]$ lysine as the label. These and other previously published experiments (Orlowski \& Sypherd, 1977) strongly suggest that little or no protein turnover occurs in actively growing Mucor cells.

\section{Discussion}

The present data indicate that Mucor yeasts and hyphae can effect regulation of the overall rate of protein synthesis by adjusting both the number of nascent polypeptide chains and the rate of nascentpolypeptide-chain elongation. The number of nascent peptide chains in the cell is the product of the number of cellular ribosomes and the percentage of ribosomes active in translation. Changing either of the latter two parameters, of course, alters the first. Both ribosome numbers and percentage of active ribosomes were measured directly in this study. The velocity of translation was determined in two different ways. The number of cellular ribosomes, the proportion of ribosomes active in protein synthesis and the velocity of ribosome movement along the mRNA all varied with the cellular growth rate. All of these parameters appeared to change independently of one another, with the net rate of protein synthesis apparently representing a synergy of all three mechanisms. The results of this work agree more with the findings of Bonven \& Gulløv (1979) than with any of the other studies cited in the introduction. Bonven \& Gulløv (1979) found that both the velocity of translation and the percentage of ribosomes active in translation varied with the growth rate. As mentioned above, the other studies using fungal material reported a change in only one (Boehlke \& Friesen, 1975; Waldron et al., 1977) or none (Alberghina \& Sturani, 1975) of these parameters as the cellular growth rate changed. 


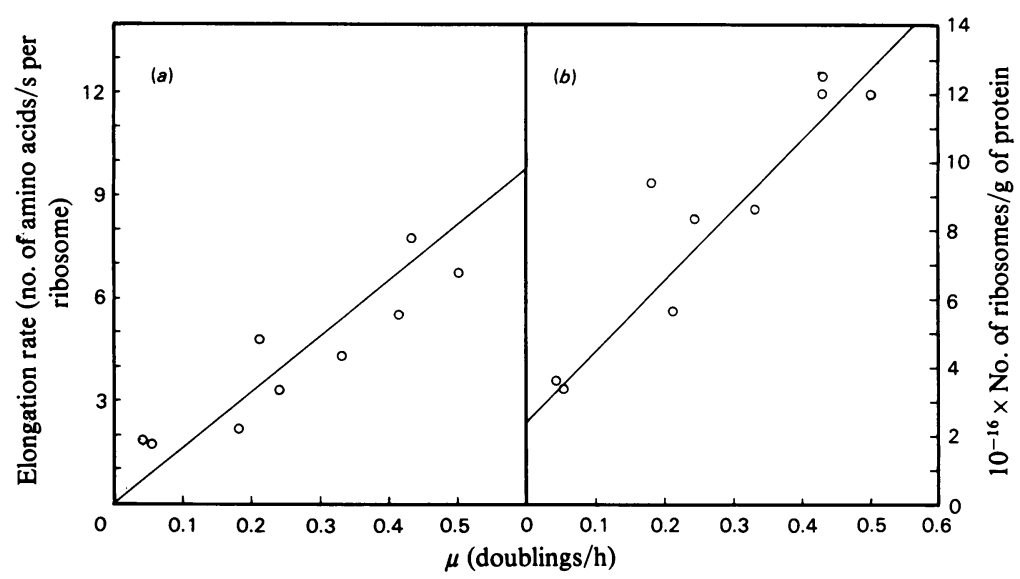

Fig. 2. Polypeptide-chain elongation rate (a) and cellular ribosome density (b) as a function of growth rate Data are taken from Tables 1 and 2.

Table 3. Calculated transit times of mRNA translation in Mucor yeasts and hyphae at various growth rates For full details, see the Materials and methods section. 'YPG' is yeast-peptone-glucose medium. The other media contain vitamins and salts as described in the Materials and methods section, glucose (Glc) as carbon source, and glutamate $(\mathrm{Glu})$ and $\left(\mathrm{NH}_{4}\right)_{2} \mathrm{SO}_{4}\left(\mathrm{NH}_{3}\right)$, or urea, as nitrogen source.

\begin{tabular}{|c|c|c|c|c|c|c|}
\hline \multirow{2}{*}{$\begin{array}{c}\text { Cell } \\
\text { morphology }\end{array}$} & \multicolumn{2}{|c|}{ Growth conditions } & \multirow{2}{*}{$\stackrel{\mu}{\mu}$} & \multirow{2}{*}{$\begin{array}{l}\text { Transit } \\
\text { time (s) }\end{array}$} & \multirow{2}{*}{$\begin{array}{l}\text { Peptide elongation } \\
\text { rate (amino acid } \\
\text { molecules added/s } \\
\text { per ribosome) }\end{array}$} & \multirow{2}{*}{$\begin{array}{c}\text { Average } \\
\text { protein } \\
\text { mol.wt. }\end{array}$} \\
\hline & Medium & Atmosphere & & & & \\
\hline $\begin{array}{l}\text { Yeasts } \\
\text { Yeasts } \\
\text { Yeasts } \\
\text { Hyphae } \\
\text { Hyphae }\end{array}$ & $\begin{array}{l}\text { YPG } \\
\text { YPG } \\
\text { Glc-Glu-NH } \\
\text { YPG } \\
\text { Glc-urea }\end{array}$ & $\begin{array}{l}\mathrm{N}_{2} \\
\mathrm{CO}_{2} \\
\mathrm{CO}_{2} \\
\mathrm{Air} \\
\mathrm{Air}\end{array}$ & $\begin{array}{l}0.434 \\
0.179 \\
0.050 \\
0.500 \\
0.240\end{array}$ & $\begin{array}{l}150 \\
366 \\
450 \\
114 \\
228\end{array}$ & $\begin{array}{l}5.5 \\
2.2 \\
1.8 \\
6.7 \\
3.3\end{array}$ & $\begin{array}{l}9.9 \times 10^{4} \\
9.6 \times 10^{4} \\
9.7 \times 10^{4} \\
9.2 \times 10^{4} \\
9.2 \times 10^{4}\end{array}$ \\
\hline
\end{tabular}

Alberghina \& Sturani (1975) observed a consistently low $(50 \%)$ proportion of active ribosomes in $N$. crassa, whereas Boehlke \& Friesen (1975) reported a constant high percentage $(90 \%)$ of active ribosomes in $S$. cerevisiae. The latter authors used lysed spheroplasts to make this determination, a condition leading to spuriously high values, as demonstrated by Bonven \& Gulløv (1979). The Neurospora study (Alberghina \& Sturani, 1975) was the only work other than studies on Mucor that used a filamentous fungus. Physiologically and morphologically normal cells were broken under liquid $\mathrm{N}_{2}$ in each case. Previous studies with $M$ ucor have shown that the percentage of active ribosomes in hyphal cells can be as low as reported for $N$. crassa, but the values are closely correlated with the stage of hyphal development (Orlowski \& Sypherd, $1978 a, c)$. The general pattern was for the fastestgrowing hyphae with well-developed germ tubes to have the lowest percentage of active ribosomes. This is why cell morphology was so rigorously controlled in the present study. Whether it was even considered in the Neurospora study is not known.

The relationship between growth rate and the active ribosome population in Mucor yeasts was qualitatively similar to that reported for Saccharomyces yeasts; however, the very low values reported in slow-growing cells (Waldron et al., 1977; Bonven \& Gulløv, 1979) were never seen. Bonven \& Gulløv (1979) reported $36 \%$ active ribosomes in $S$. cerevisiae growing at 0.17 doubling/h, and Waldron et al. (1977) indicated $50 \%$ active ribosomes in the same organism growing at 0.3 doubling/h. Mucor yeasts growing at much slower rates had a substantially higher percentage of active ribosomes (Table 1).

Though the Bonven \& Gulløv (1979) study agrees with the present findings on an adjustable rate of peptide-chain elongation, the work of Waldron et al. (1977) does not. Both groups would like to suggest that slow-growing yeasts, as previously reported for bacteria (Koch, 1971), have a large excess of 


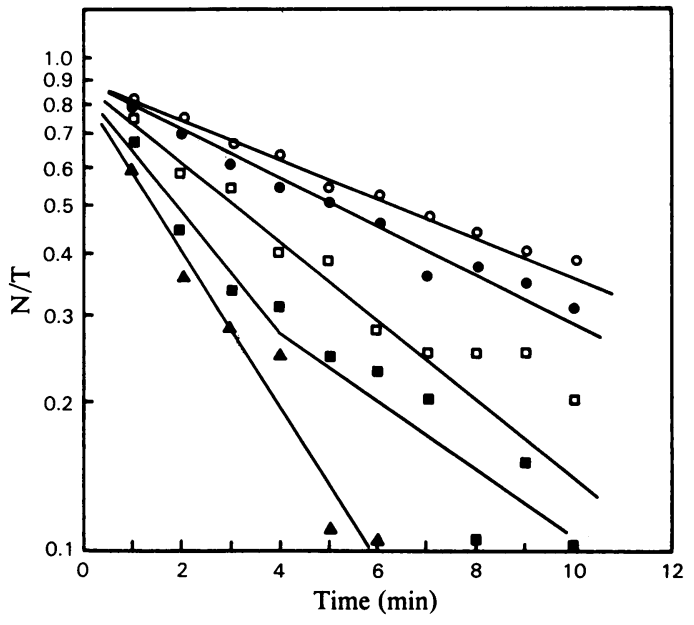

Fig. 3. Kinetics of flow of radioactive amino acids from nascent polypeptides to completed and released protein molecules

Results are represented as the rate of decay of the fraction of total incorporated label occurring in the ribosome-bound (nascent protein) fraction $(\mathrm{N} / \mathrm{T})$. Symbols: 0 , yeasts grown under $\mathrm{CO}_{2}$ in YPG medium; $\mathrm{O}$, yeasts grown under $\mathrm{CO}_{2}$ in the defined medium with glucose as carbon source and glutamate plus $\left(\mathrm{NH}_{4}\right)_{2} \mathrm{SO}_{4}$ as nitrogen source; $\square$, yeasts grown under $\mathrm{N}_{2}$ in YPG medium; $\square$, hyphae grown under air in the defined medium with glucose as carbon source and urea as nitrogen source; $\mathbf{\Delta}$, hyphae grown under air in YPG medium. Strain leu-2A was used in all these experiments.

inactive ribosomes present in a 'standby' status until pressed into immediate service by a sudden improvement in the environment. The immediate mobilization of these excess ribosomes, rather than an increase in the speed of translation, would initiate the increased rate of protein synthesis upon a shift-up. The support for such a notion is not very impressive for Mucor yeasts, and non-existent for Mucor hyphae. One priority for future work with the Mucor system will be nutritional shift-up experiments. If previous $\mathrm{CO}_{2}$-to-air shifts (with accompanying morphogenesis) (Orlowski \& Sypherd, 1978 a) prove to be the equivalent of a nutritional shift-up, the organism will respond to the improved conditions by immediately increasing the peptidechain elongation rate, but only gradually increasing the number of cellular ribosomes. The percentage of active ribosomes may not change very suddenly or very much. Certainly much remains to be done before a complete understanding of the mechanisms controlling protein synthesis in eukaryotes, or merely in fungi, is possible. Indeed, it still remains to be determined whether different fungi use alter-

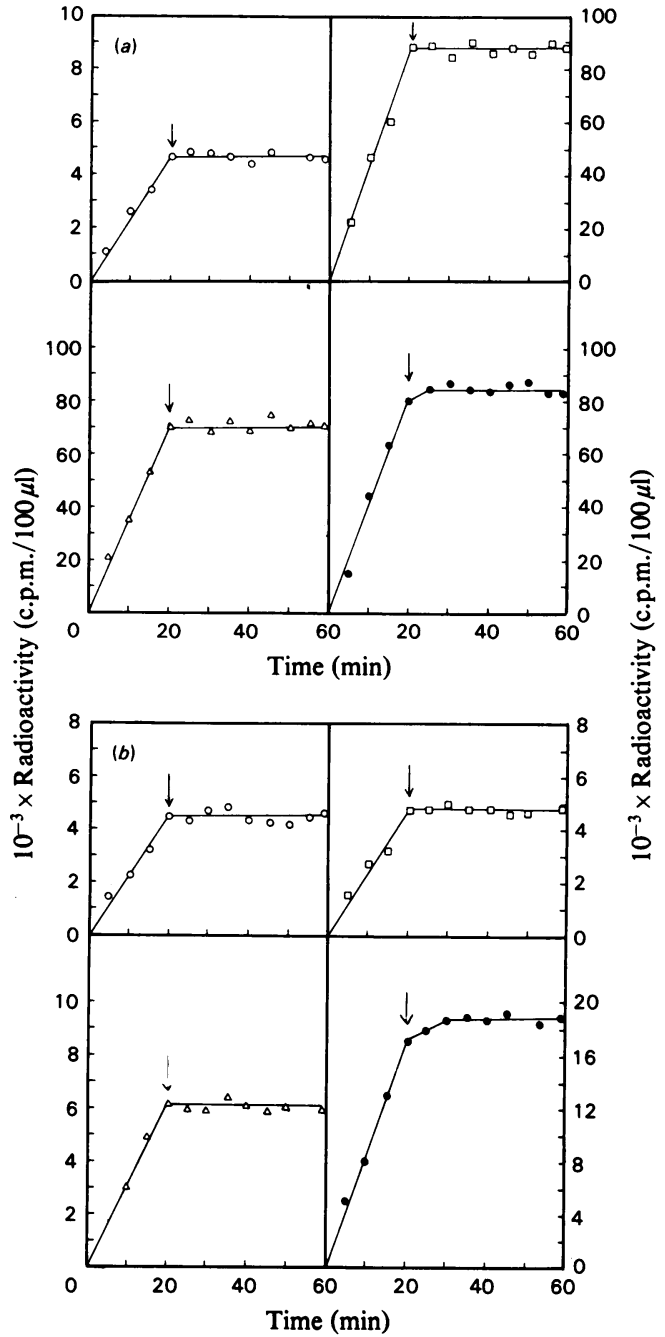

Fig. 4. Pulse-chase assay for protein turnover

Results for hyphae grown aerobically in various media are shown. The pulse with a radioactive amino acid was begun at zero time. The chase with unlabelled amino acid was commenced at $20 \mathrm{~min}$ (arrows). (a) L- $\left[{ }^{14} \mathrm{C}\right]$ valine label; (b) $\mathrm{L}-\left[{ }^{14} \mathrm{C}\right]$ proline label. Symbols: O, YPG medium; $\square$, defined medium (see the Materials and methods section) with glucose and $\left(\mathrm{NH}_{4}\right)_{2} \mathrm{SO}_{4} ; \Delta$, defined medium with glucose and urea; $O$, defined medium with mannitol and $\left(\mathrm{NH}_{4}\right)_{2} \mathrm{SO}_{4}$. Strain $1216 \mathrm{~B}$ was used in all experiments.

native strategies or one universal mechanism to regulate the rate of protein synthesis.

\section{References}

Alberghina, F. A. M. \& Sturani, E. (1975) J. Biol. Chem. 250, 4381-4388 
Boehlke, K. W. \& Friesen, J. D. (1975) J. Bacteriol. 121, 429-433

Bonven, B. \& Gulløv, K. (1979) Mol. Gen. Genet. 170, 225-230

Cheung, S. C., Kobayashi, G. S., Schlessinger, D. \& Medoff, G. (1974) J. Gen. Microbiol. 82, 301-307

Coffman, R. L., Norris, T. E. \& Koch, A. L. (1971) J. Mol. Biol. 60, 1-19

Dalbow, D. G. \& Young, R. (1975) Biochem. J. 150, 13-20

Fan, H. \& Penman, S. (1970) J. Mol. Biol. 50, 655670

Forchhammer, J. \& Lindahl, L. (1971) J. Mol. Biol. 55, 563-568

Gausing, K. (1972) J. Mol. Biol. 71, 529-545

Haschemeyer, A. E. V. (1969) Proc. Natl. Acad. Sci. U.S.A. 62, 128-135

Koch, A. L. (1971) Adv. Microb. Physiol. 6, 147-217

Lovett, J. S. \& Haselby, J. A. (1971) Arch. Microbiol. 80, 191-204

Lowry, O. H., Rosebrough, N. J., Farr, A. L. \& Randall, R. J. (1951) J. Biol. Chem. 193, 265-275
Martin, S. E. \& Iandolo, J. J. (1975) J. Bacteriol. 122, 1136-1143

Orlowski, M. (1979) Biochem. J. 182, 547-554

Orlowski, M. \& Sypherd, P. S. (1977) J. Bacteriol. 132, 209-218

Orlowski, M. \& Sypherd, P. S. (1978a) Biochemistry 17, 569-575

Orlowski, M. \& Sypherd, P. S. (1978b) Arch. Microbiol. 119, 145-152

Orlowski, M. \& Sypherd, P. S. (1978c) J. Bacteriol. 134, 76-83

Peters, J. \& Sypherd, P. S. (1978) J. Gen. Microbiol. 105, $77-81$

Scornik, O. A. (1974) J. Biol. Chem. 249, 3876-3883

Sypherd, P. S., Orlowski, M. \& Peters, J. (1979) in Microbiology 1979 (Schlessinger, D., ed.), pp. 224227, American Society for Microbiology, Washington, D.C.

Waldron, C., Jund, R. \& Lacroute, F. (1977) Biochem. J. $168,409-415$

Young, R. \& Bremer, H. (1976) Biochem. J. 160, 185-194 